\title{
Effects of Different Levels of Fertilization with Hen Droppings on the Production and Chemical Composition of Pennisetum clandestinum (Poaceae)
}

\author{
Wauffo David Fokom ${ }^{1,2}$, Fernand Tendonkeng2, Gilles Jiope Azangue ${ }^{3 *}$, Emile Miégoué2, \\ France-Gina Tobou Djoumessi², Nyah Cédric Kwayep², Mama Mouchili ${ }^{2}$ \\ ${ }^{1}$ Institute of Agricultural Research for development (IRAD), Bangangté, Cameroon \\ ${ }^{2}$ Department of Animal Science, Faculty of Agronomy and Agricultural Sciences, University of Dschang, Cameroon \\ ${ }^{3}$ Department of Plant Biology, Faculty of Science, University of Dschang, Cameroon \\ Email: *azangilles@yahoo.fr
}

How to cite this paper: Fokom, W.D., Tendonkeng, F., Azangue, G.J., Miégoué, E., Djoumessi, F.-G.T., Kwayep, N.C. and Mouchili, M. (2021) Effects of Different Levels of Fertilization with Hen Droppings on the Production and Chemical Composition of Pennisetum clandestinum (Poaceae). Open Journal of Animal Sciences, 11, 543-558. https://doi.org/10.4236/ojas.2021.114037

Received: March 1, 2021

Accepted: August 29, 2021

Published: September 1, 2021

Copyright $\odot 2021$ by author(s) and Scientific Research Publishing Inc. This work is licensed under the Creative Commons Attribution International License (CC BY 4.0).

http://creativecommons.org/licenses/by/4.0/ (c) (i) Open Access

\begin{abstract}
The use of organic manures, constitute an alternative to that of polluting artificial fertilizers. In this study, the effect of various levels of hen droppings fertilization on the production of biomass, chemical composition and carrying capacity of $P$. clandestinum were evaluated at the Research and Experimental Farm (REF) and at the Animal Nutrition and Feeding Laboratory of the University of Dschang, between April and September 2016. A completely randomized block design comparing three nitrogen level of fertilization in hen droppings form $(0 ; 100$ and $200 \mathrm{~kg} \mathrm{~N} / \mathrm{ha})$ on $4 \mathrm{~m}^{2}$ plot of $P$. clandestinum were used. Each treatment was carried out in four replications for a total of 12 experimental plots. Then a sample of $500 \mathrm{~g}$ of forage has been collected in the center of each plot, then dried and used for the evaluation of the biomass and the chemical composition of $P$. clandestinum, according to the level of fertilization and the cutting frequency. The results showed that the fertilization with the hen droppings positively influenced $(\mathrm{p}<0.05)$ regeneration at the first cutting frequency and the highest value $(47.12 \mathrm{~cm})$ was obtained with of $200 \mathrm{~kg}$ $\mathrm{N} /$ ha rate of fertilization. The biomass of this fodder increased significantly ( $\mathrm{p}$ $<0.05$ ) with the level of fertilization with hen droppings. Besides, it decreases with the increasing cutting of frequency whatever the level of fertilization. Independently of the fertilization and the cutting frequency, the maximum biomass $(6.22 \mathrm{t} \mathrm{DM} / \mathrm{ha}$ ) was obtained with the first cutting at the $200 \mathrm{~kg} \mathrm{~N} / \mathrm{ha}$ of hen droppings fertilization. The fertilization influenced in variable way the chemical composition of $P$. clandestinum. The dry matter and organic matter
\end{abstract}


content decrease with the level of fertilization and the highest values $(83.79 \%$ and $89.39 \%$ respectively for the DM and OM) were obtained on the control plot at the third and the first cutting. Moreover, the ash and crude protein contents increased significantly $(\mathrm{p}<0.05)$ with the cutting frequency of cutting and the level of fertilization applied. The highest ash (19.34\% DM) and CP (20.04\% DM) contents were obtained with of $200 \mathrm{~kg} \mathrm{~N} / \mathrm{ha}$ of hen droppings at the second cutting frequency.

\section{Keywords}

Fertilization, Hen Droppings, Biomass, Chemical Composition, Pennisetum clandestinum

\section{Introduction}

Pastures areas are decreasing in the soudano-sahelian part of Africa, because of increasing demography. This reality induces the displacement of farmers, searching for new pasture areas. In addition, breeding is nowadays confronted with the extension of cultures and counter-season cultures which reduce the remaining pasturable areas and blocks circulation, watering, and livestock feeding [1] [2]. Those conditions lead to the development of conflicts between farmers and stockbreeders for the use of rural areas [3] [4]. To face the situation it is therefore imperative for stockbreeders to search and adopt the new system of control animal management [5].

Consequently, an improvement of animal productivity must include not only the control of the production system but also the introduction and intensification of high-output fodder production [4]. Many fodder plants can thus be adopted such as Pennisetum clandestinum. This grass is a slow starter, but, its longevity being over a long period, as well as its resistance to weed invasion [6]. Excellent quality and particularly interesting on uplands, it is suitable for both grazing and hand mowing. It is one of the plants with very good feed values within the tropical grass family, which justifies its use in ruminant breeding [6]. The cultivation of this fodder would ensure the availability of feed for livestock both in favorable periods (rainy season) and in unfavorable periods (dry season) [7].

Intensification of this culture involves using organic or chemical fertilizers. Although its short-term beneficial effects on the fodders' quality and quantity, bad use of mineral fertilizers can constitute a source of environmental pollution, and also considerably increase the production costs of fodder. Vis-a-vis of this situation, fodder growers are more and more seeking other sources of fertilizers, which can improve nutritional quality of fodder while being non-pollutant [8]. Such fertilizers can be organic manures (farm manure, compost...).

Former studies showed the beneficial effects of hen-dropping fertilization, on the production and chemical composition of fodder. Indeed, the studies carried out by Nono [9], Olanite [10], Kamgue [11] and Azangue et al. [12] [13] on 
biomass production of $B$ ruziziensis showed that fertilization with hen droppings had improved the biomass production and chemical composition of this fodder plant. However, very few studies have been carried out on the use of organic manures in the culture and nutritional value of Pennisetum clandestinum.

\section{Material and Methods}

\subsection{Study Area}

The study was carried out at the Research and Experimental Farm (REF) and at the Animal Nutrition and feeding Laboratory of the University of Dschang. Dschang is located in the West Cameroon region, in the Menoua division, Dschang subdivision, at $05^{\circ} 20^{\prime}$ north latitude and $10^{\circ} 03^{\prime}$ east longitude [14]. The climate of the entire territory is a Cameroonian equatorial climate with mountainous features determined by the altitude, the average altitude of which is $1400 \mathrm{~m}$. It is characterized by a rainy season from mid-March to mid-November and a dry season from mid-November to mid-March [15] [16]. The average temperature of the hottest month (February) is $25^{\circ} \mathrm{C}$ and the average temperature of the coolest month is $19^{\circ} \mathrm{C}$ and is in July or August. The annual sunshine is 1800 hours, the relative humidity varying between $40 \%$ and $97 \%$. Rainfall varies between 1500 and $2000 \mathrm{~mm}$ per year [4] [17].

\subsection{Soil Analysis and Experimental Design}

An analysis of the chemical composition and texture of the soil was made before the tillage for stump to be put in place. Samples were collected on the site in horizon 0 to $20 \mathrm{~cm}$ of depth. The chemical analysis of the ground has been carried out at the Soil Analysis and Environmental Chemistry Laboratory of the University of Dschang, following the method described by Pauwels et al. [18]. Results of this analysis are presented in Table 1.

The stumps of Pennisetum clandestinum were established according to a factorial device comparing three levels of nitrogenized fertilization in the form of hen droppings (0; 100 and $200 \mathrm{~kg} \mathrm{~N} / \mathrm{ha}$ ) and four cutting frequencies in four replicals on elementary plots of $4 \mathrm{~m}^{2}(2 \mathrm{~m} \times 2 \mathrm{~m})$ for a total of 12 experimental plots.

\subsection{Origin and Chemical Composition of Hens' Droppings}

For this study, hens' droppings used as a source of fertilizer were obtained from a producer's farm in the Mifi division (Bafoussam). This organic fertilizer was produced by table egg laying hens raised in batteries. A sample of these droppings was analyzed by the method described by Pauwels [18] at the Soil Analysis and Environmental Chemistry Laboratory of the University of Dschang. Table 2 presents the analysis of the chemical composition of hen droppings.

\subsection{Setting and Fertilization of Pieces}

Pennisetum clandestinum was set up by stumps. Each stump carrying one or 
Table 1. Soil physico-chemical composition.

\begin{tabular}{|c|c|}
\hline \multicolumn{2}{|c|}{ Texture percentage (\%) } \\
\hline Sand & 15 \\
\hline Silt & 60 \\
\hline Clay & 25 \\
\hline \multicolumn{2}{|c|}{ Reaction of the ground } \\
\hline Water $\mathrm{pH}$ & 5.5 \\
\hline $\mathrm{KCl} \mathrm{pH}$ & 4.9 \\
\hline \multicolumn{2}{|c|}{ Organic matter percentage (\%) } \\
\hline OC & 7.0 \\
\hline $\mathrm{OM}$ & 12 \\
\hline Total N & 0.6 \\
\hline \multicolumn{2}{|c|}{ Exchangeable cations $\mathrm{cmol}(+) / \mathrm{Kg}$} \\
\hline $\mathrm{Ca}$ & 2.06 \\
\hline $\mathrm{Mg}$ & 0.43 \\
\hline $\mathrm{K}$ & 0.2 \\
\hline $\mathrm{Na}$ & 0.01 \\
\hline \multicolumn{2}{|c|}{ Cation exchange capacity $\mathrm{cmol}(+) / \mathrm{Kg} 7.84$} \\
\hline \multicolumn{2}{|c|}{ Assimilable phosphorus (mg/kg) } \\
\hline Bray II & 0.5 \\
\hline & \\
\hline
\end{tabular}

Table 2. Chemical composition of hen droppings.

\begin{tabular}{|c|c|c|c|c|c|c|c|}
\hline & \multicolumn{7}{|c|}{ Mineral nutrients } \\
\hline & $\begin{array}{c}\mathrm{N} \\
(\mathrm{g} / \mathrm{kg})\end{array}$ & $\begin{array}{c}\mathrm{P}_{2} \mathrm{O}_{5} \\
(\mathrm{mg} / \mathrm{kg})\end{array}$ & $\begin{array}{c}\mathrm{K}_{2} \mathrm{O} \\
(\mathrm{mg} / \mathrm{kg})\end{array}$ & $\begin{array}{c}\mathrm{Ca} \\
(\mathrm{mg} / \mathrm{kg})\end{array}$ & $\begin{array}{c}\mathrm{Na} \\
(\mathrm{mg} / \mathrm{kg})\end{array}$ & $\begin{array}{c}\mathrm{Mg} \\
(\mathrm{mg} / \mathrm{kg})\end{array}$ & $\begin{array}{c}\mathrm{Fe} \\
(\mathrm{mg} / \mathrm{kg})\end{array}$ \\
\hline Quantity & 20.30 & 1.83 & 1253 & 19280 & 55 & 15017 & 0.2 \\
\hline
\end{tabular}

two stems had been obtained starting from the tufts taken on the courses of the Research and Experimental Farm. They were mended manually with a $4 \mathrm{~cm}$ depth on each piece, and a spacing of $25 \times 25 \mathrm{~cm}$ between the seedlings. Simple superphosphate with $25 \%$ (100 $\mathrm{kg}$ with hectare, is $60 \mathrm{~g}$ per experimental unit) was applied to the whole experimental, pieces like funds manure. Three nitrogen amounts were defined $(0,100$ and $200 \mathrm{~kg}$ of nitrogen per hectare).

\subsection{Evaluation of Regeneration}

It was done using a scale from 0 to $100 \mathrm{~cm}$, five leveling of the plants were taken with five distinct positions along the diagonals from cutting table (at the four ends and the medium) and the average was retained as the height of regrowth for the plot during the period. 


\subsection{Biomass Inventory}

After cutting of regularization on all the plots, the samples were collected every 30 days. Using a cutting table of $1 \mathrm{~m} \times 2 \mathrm{~m}$ and quite sharp knives, plant was cut to $5 \mathrm{~cm}$ of the ground in the center of the piece on a useful surface area of $2 \mathrm{~m}^{2}$ in each piece. Fodder thus collected was weighed at the place using an electronic balance of HD60KB brand, with $60 \mathrm{~kg}$ capacity and $10 \mathrm{~g}$ of precision for the determination of the fresh mass. Sample of $500 \mathrm{~g}$ was taken and dried at $60^{\circ} \mathrm{C}$ until constant weight in a ventilated drying oven of Gallenkamp brand to estimate the dry matter (output in $\mathrm{kg}$ of DM/ha).

\subsection{Evaluation of Fodder Chemical Composition}

The analyses of thus collected various samples of Pennisetum clandestinum chemical composition were carried out in order to determine contents of the dry matter, ashes, organic matter, and total nitrogenized matters according to the methods described by AOAC [19].

\subsection{Statistical Analyses}

The data were subjected to an analysis of variance (ANOVA) according to the General Linear Model (MLG) with statistical software SPSS 21.0. When differences existed between the various treatments, the averages were separated by the Duncan multiple test 5\% significance level [20].

\section{Results}

\subsection{Effects of the Different Levels of Fertilization with Hen Droppings on the Regeneration of $\boldsymbol{P}$. Clandestinum}

Fertilization significantly $(\mathrm{p}<0.05)$ affected regeneration only at the first cutting (Table 3). Indeed, the fertilization at $200 \mathrm{~kg} \mathrm{~N} / \mathrm{ha}$ in the form of hen droppings significantly improved $(\mathrm{p}<0.05)$ regeneration of $P$. clandestinum compared to the control plot. On the other hand, no significant difference ( $\mathrm{p}>0.05)$ was observed between the control plot and the plot fertilized to $100 \mathrm{~kg} \mathrm{~N} / \mathrm{ha}$ on one hand and on the other hand between this last piece and that fertilized to $200 \mathrm{~kg}$

Table 3. Effects of the different levels of fertilization with hen droppings on the regeneration of $P$. clandestinum cut every thirty days.

\begin{tabular}{ccccc}
\hline & \multicolumn{5}{c}{ Regeneration } \\
Level of fertilization (kg N/ha) & $\mathrm{F}_{1}$ & $\mathrm{~F}_{2}$ & $\mathrm{~F}_{3}$ & $\mathrm{~F}_{4}$ \\
\cline { 2 - 5 } & $33.20^{\mathrm{a}}$ & $27.33^{\mathrm{a}}$ & $29.82^{\mathrm{a}}$ & $28.20^{\mathrm{a}}$ \\
100 & $43.04^{\mathrm{ab}}$ & $31.97^{\mathrm{a}}$ & $35.57^{\mathrm{a}}$ & $31.90^{\mathrm{a}}$ \\
200 & $47.12^{\mathrm{b}}$ & $34.12^{\mathrm{a}}$ & $39.67^{\mathrm{a}}$ & $31.17^{\mathrm{a}}$ \\
ESM & 2.34 & 1.40 & 1.91 & 0.81 \\
$\mathrm{p}$ & 0.023 & 0.123 & 0.095 & 0.136 \\
\hline
\end{tabular}

a, b: The averages carrying the same letters in the same column are not significantly different with the threshold from 5\%; p: Probability; F: Cuttings; SEM: Standard error of the mean. 
$\mathrm{N} / \mathrm{ha}$. As regards the other cuttings no significant difference $(\mathrm{p}>0.05)$ was observed between the treatments.

\subsection{Effects of Different Levels of Fertilization on Hen Droppings on the Biomass Production of $P$. Clandestinum}

Biomass was significantly improved $(\mathrm{p}<0.05)$ by the nitrogen fertilizer (Table 4). Indeed, whatever the number of the cutting, fertilization with $200 \mathrm{~kg} \mathrm{~N} / \mathrm{ha}$ in the form of hen droppings significantly increased $(\mathrm{p}<0.05)$ the biomass of $P$. clandestinum compared to the control plot. No significant difference $(p>0.05)$ was observed between amounts 0 and $100 \mathrm{~kg} \mathrm{~N} / \mathrm{ha}$ for cuttings 2 and 4 on one hand; and on the other hand, between the amounts 100 and $200 \mathrm{~kg} \mathrm{~N} / \mathrm{ha}$ for cuttings 3 and 4 . As a whole, the highest biomass ( $6.22 \mathrm{t} \mathrm{DM} / \mathrm{ha}$ ) was obtained with the first cutting with the weakest amount $200 \mathrm{~kg} \mathrm{~N} / \mathrm{ha}$ and with the third cutting with the pilot amount (1.2 t DM/ha). Average and total biomasses of $P$. clandestinum increased significantly $(\mathrm{p}<0.05)$ with the growing level of fertilization to hen droppings.

\subsection{Effects of Different Levels of Fertilization to Hen Droppings on the Chemical Composition of $P$. Clandestinum}

\subsubsection{Effects on the Average Contents of DM and OM}

Fertilization with hens droppings significantly affected $(\mathrm{p}<0.05)$ the content of DM with the first, but does not have any significant effect $(p>0.05)$ on the content of DM with the second, third and fourth cuttings frequencies (Table 5). Moreover, the dry matter content dropped with the increased level of fertilization and the low values were obtained with the level of $200 \mathrm{~kg} \mathrm{~N} / \mathrm{ha}$. Whatever the cutting frequency considered, the dry matter content obtained of the plants from plots fertilized with $100 \mathrm{~kg} \mathrm{~N} / \mathrm{ha}$ at the first cutting frequency were compared $(p>0.05)$ with those obtained in the plants from the unfertilized plot on one hand and $200 \mathrm{~kg} \mathrm{~N} / \mathrm{ha}$ on the other hand.

In addition, no significant difference $(p>0.05)$ was observed between treatments as in the second and fourth frequencies (Table 5). On the other hand, with the first and the third ones, organic matter content was significantly $(\mathrm{p}<$ $0.05)$ reduced by the nitrogen fertilization. Indeed, for these cutting frequencies,

Table 4. Effects of different levels of fertilization to hen droppings on the production of biomass (t/ha of DM) of $P$. clandestinum cut every thirty days.

\begin{tabular}{|c|c|c|c|c|c|c|}
\hline \multirow{2}{*}{$\begin{array}{l}\text { Level of fertilization } \\
\qquad(\mathrm{kg} \mathrm{N} / \mathrm{ha})\end{array}$} & \multicolumn{4}{|c|}{ Biomass (t DM/ha) } & \multirow{2}{*}{$\begin{array}{c}\text { Total } \\
\text { (t DM/ha) }\end{array}$} & \multirow{2}{*}{$\begin{array}{c}\text { Means } \\
\text { (t DM/ha) }\end{array}$} \\
\hline & $\mathrm{F}_{1}$ & $\mathrm{~F}_{2}$ & $\mathrm{~F}_{3}$ & $\mathrm{~F}_{4}$ & & \\
\hline 0 & $2.89^{\mathrm{a}}$ & $1.49^{\mathrm{a}}$ & $1.2^{\mathrm{a}}$ & $1.31^{\mathrm{a}}$ & $6.89^{\mathrm{a}}$ & $1.72^{\mathrm{a}}$ \\
\hline 100 & $4.43^{\mathrm{b}}$ & $1.76^{\mathrm{a}}$ & $1.78^{\mathrm{b}}$ & $1.73^{\mathrm{ab}}$ & $9.7^{\mathrm{b}}$ & $2.42^{\mathrm{b}}$ \\
\hline 200 & $6.22^{c}$ & $2.38^{\mathrm{b}}$ & $1.78^{\mathrm{b}}$ & $1.72^{\mathrm{b}}$ & $12.3^{\mathrm{c}}$ & $3.07^{c}$ \\
\hline SEM & 0.44 & 0.14 & 0.10 & 0.11 & 0.71 & 0.18 \\
\hline $\mathrm{p}$ & 0.001 & 0.017 & 0.004 & 0.049 & 0.001 & 0.001 \\
\hline
\end{tabular}

$\mathrm{a}, \mathrm{b}, \mathrm{c}$ : The averages carrying the same letters in the same column are not significantly different with the threshold from 5\%; p: Probability; F: Cuttings; SEM: Standard error of the mean. 
Table 5. Effects of the different levels of fertilization to hen droppings on the average contents of DM and OM of $P$. clandestinum cut every thirty days.

\begin{tabular}{cccccccccccc}
\hline \multirow{2}{*}{$\begin{array}{c}\text { Level of } \\
\text { fertilization } \\
(\mathrm{kgN} / \mathrm{ha})\end{array}$} & $\mathrm{F}_{1}$ & $\mathrm{~F}_{2}$ & $\mathrm{~F}_{3}$ & $\mathrm{~F}_{4}$ & Means & $\mathrm{F}_{1}$ & $\mathrm{~F}_{2}$ & $\mathrm{~F}_{3}$ & $\mathrm{~F}_{4}$ & Means \\
\cline { 2 - 12 } & $83.74^{\mathrm{b}}$ & $82.16^{\mathrm{a}}$ & $83.79^{\mathrm{a}}$ & $81.62^{\mathrm{a}}$ & $82.83^{\mathrm{b}}$ & $89.39^{\mathrm{b}}$ & $86.22^{\mathrm{a}}$ & $86.21^{\mathrm{b}}$ & $83.01^{\mathrm{a}}$ & $86.21^{\mathrm{b}}$ \\
100 & $81.48^{\mathrm{ab}}$ & $82.36^{\mathrm{a}}$ & $80.93^{\mathrm{a}}$ & $81.93^{\mathrm{a}}$ & $81.67^{\mathrm{b}}$ & $87.48^{\mathrm{ab}}$ & $86.68^{\mathrm{a}}$ & $83.61^{\mathrm{ab}}$ & $84.58^{\mathrm{a}}$ & $85.59^{\mathrm{ab}}$ \\
200 & $78.96^{\mathrm{a}}$ & $74.58^{\mathrm{a}}$ & $78.27^{\mathrm{a}}$ & $80.08^{\mathrm{a}}$ & $77.97^{\mathrm{a}}$ & $85.45^{\mathrm{a}}$ & $81.65^{\mathrm{a}}$ & $80.27^{\mathrm{a}}$ & $83.06^{\mathrm{a}}$ & $82.61^{\mathrm{a}}$ \\
$\mathrm{SEM}$ & 0.71 & 1.59 & 1.10 & 1.10 & 0.83 & 0.63 & 1.68 & 0.85 & 0.74 & 0.67 \\
$\mathrm{p}$ & 0.005 & 0.056 & 0.107 & 0.795 & 0.022 & 0.017 & 0.137 & 0.039 & 0.656 & 0.046 \\
\hline
\end{tabular}

a, b: The averages carrying the same letters in the same column are not significantly different with the threshold from 5\%; p: Probability; F: Cuttings; SEM: Standard error of the mean.

on plot fertilized with $100 \mathrm{~kg} \mathrm{~N} / \mathrm{ha}$, organic matter content was comparable ( $\mathrm{p}>$ 0.05 ) with that of forages obtained from unfertilized plots. On one hand and that of plots fertilized with $200 \mathrm{~kg} \mathrm{~N} / \mathrm{ha}$ on the other hand. However, the control plot gave the significantly highest value $(\mathrm{p}<0.05)$ and the $200 \mathrm{~kg} \mathrm{~N} / \mathrm{ha}$ fertilized plot, the lowest value.

\subsubsection{Effects on the Average Contents of Ash and Rough Protein}

Fertilization with hens droppings has no significant effect $(p>0.05)$ on the ash content as much with the second than with the fourth frequency (Table 6). On the other hand, fertilization significantly increased $(p<0.05)$ the ash content of the first and the third cuttings. Indeed, for these frequencies, the ashes content obtained in the plots fertilized with $100 \mathrm{~kg} \mathrm{~N} / \mathrm{ha}$ were compared $(\mathrm{p}>0.05)$ with those obtained in the unfertilized plot and the plots fertilized with $200 \mathrm{~kg} \mathrm{~N} / \mathrm{ha}$. However, the fertilized pieces with $200 \mathrm{~kg} \mathrm{~N} /$ ha gave significantly highest values $(\mathrm{p}<0.05)$ and the pilot pieces the lowest values. The same tendency was observed with the average ash contents.

Crude protein content of $P$. clandestinum significantly increased $(\mathrm{p}<0.05)$ with the growing level of fertilization to hen droppings (Table 6). Indeed, with the $\mathrm{F}_{1}, \mathrm{~F}_{2}$ and $\mathrm{F}_{4}$ cuttings, the rate of crude protein content of $P$. clandestinum obtained in the control plots was significantly $(\mathrm{p}<0.05)$ weaker than those obtained on the plots fertilized with $100 \mathrm{~kg} \mathrm{~N} / \mathrm{ha}$ and $200 \mathrm{~kg} \mathrm{~N} / \mathrm{ha}$ which were comparable ( $p>0.05$ ) between them. On the other hand, with the third cutting, rate of crude protein obtained on the control plots fodder and that obtained from fertilized pieces fodder with $100 \mathrm{~kg} \mathrm{~N} / \mathrm{ha}$ were comparable $(\mathrm{p}>0.05)$ but, significantly $(\mathrm{p}<0.05)$ weaker than those of the fodder obtained on the fertilized pieces with $200 \mathrm{~kg} \mathrm{~N} / \mathrm{ha}$. The same tendency was observed with the average proteins contents.

\subsubsection{Effects of the Number of Cutting and the Fertilization on the Production of Biomass and the Chemical Composition of P. Clandestinum}

1) Biomass variation according to the number of cutting 
Table 6. Effects of the different levels of fertilization to the hen droppings on the average contents of ash and crude protein (\% DM) of $P$. clandestinum cut every thirty days.

\begin{tabular}{|c|c|c|c|c|c|c|c|c|c|c|}
\hline \multirow{2}{*}{$\begin{array}{l}\text { Level of } \\
\text { fertilization } \\
(\mathrm{kgN} / \mathrm{ha})\end{array}$} & \multicolumn{5}{|c|}{ Ash } & \multicolumn{5}{|c|}{ Crude proteins } \\
\hline & $\mathrm{F}_{1}$ & $\mathrm{~F}_{2}$ & $\mathrm{~F}_{3}$ & $\mathrm{~F}_{4}$ & Means & $\mathrm{F}_{1}$ & $\mathrm{~F}_{2}$ & $\mathrm{~F}_{3}$ & $\mathrm{~F}_{4}$ & Means \\
\hline 0 & $10.61^{\mathrm{a}}$ & $13.78^{\mathrm{a}}$ & $13.79^{\mathrm{a}}$ & $16.98^{\mathrm{a}}$ & $13.79^{\mathrm{a}}$ & $8.31^{\mathrm{a}}$ & $13.18^{\mathrm{a}}$ & $13.05^{\mathrm{a}}$ & $10.87^{\mathrm{a}}$ & $11.35^{\mathrm{a}}$ \\
\hline 100 & $12.51^{\mathrm{ab}}$ & $13.32^{\mathrm{a}}$ & $18.39^{\mathrm{ab}}$ & $15.41^{\mathrm{a}}$ & $14.9^{\mathrm{ab}}$ & $13.08^{\mathrm{b}}$ & $16.93^{\mathrm{b}}$ & $15.67^{\mathrm{a}}$ & $14.66^{\mathrm{b}}$ & $15.10^{\mathrm{a}}$ \\
\hline 200 & $14.55^{\mathrm{b}}$ & $18.34^{\mathrm{a}}$ & $19.72^{\mathrm{b}}$ & $16.94^{\mathrm{a}}$ & $17.39^{\mathrm{b}}$ & $13.71^{\mathrm{b}}$ & $20.04^{\mathrm{b}}$ & $19.77^{\mathrm{b}}$ & $14.60^{\mathrm{b}}$ & $817.02^{\mathrm{b}}$ \\
\hline SEM & 0.63 & 1.38 & 0.85 & 0.74 & 0.83 & 0.23 & 1.01 & 1.02 & 0.70 & 0.75 \\
\hline $\mathrm{p}$ & 0.017 & 0.137 & 0.039 & 0.656 & 0.022 & 0.001 & 0.005 & 0.008 & 0.016 & 0.001 \\
\hline
\end{tabular}

a, b: The averages carrying the same letters in the same column are not significantly different with the threshold from 5\%; p: Probability; F: Cuttings; SEM: Standard error of the mean.

The increase number of cutting significantly $(\mathrm{p}<0.05)$ lowered the production of biomass, whatever the level of hen droppings fertilization (Figure 1). Indeed, the biomass obtained with the first cutting was significantly $(\mathrm{p}<0.05)$ higher than those obtained in the second, third and fourth cuttings. These three last cuts gave biomasses which remained comparable $(\mathrm{p}>0.05)$ between them whatever the treatment. On average, the tendency remained the same.

2) Variation of the dry matters content according to the number of cutting

The number of cutting did not have any significant effect $(\mathrm{p}>0.05)$ on the content of dry matter whatever the level of fertilization to hen droppings (Figure 2).

3) Variation of organic matter content according to the number of cutting

The organic matter contents dropped with the frequency of cutting and this decrease was significant $(p<0.05)$ between the cuttings $F_{1}$ and $F_{4}$. The values of organic matter obtained with the first, second and third cuttings remained comparable ( $\mathrm{p}>0.05$ ) for the amounts 100 and $200 \mathrm{~kg} \mathrm{~N} / \mathrm{ha}$. The same tendency was observed between the averages. The number of cutting did not significantly $(\mathrm{p}<0.05)$ affect the content of organic matter of $P$. clandestinum on the control plot (Figure 3).

\section{4) Variation of ash content according to the number of cutting}

The number of cutting did not significantly $(p<0.05)$ affect. The ash contents increased with the frequency of cutting and this increase was significant $(\mathrm{p}<$ 0.05 ) between the cuttings $F_{1}$ and $F_{4}$. On the other levels of fertilization to the hen droppings, the ash contents of fodder were comparable ( $p>0.05)$ whatever the frequency of cutting, as well as with the average contents of ash. No significant effect was observed with the ash content of $P$. clandestinum of the control plot (Figure 4).

5) Variation of the content of rough protein according to the number of cutting

The fodders crude protein contents $(\mathrm{p}<0.05)$ were significantly affected by the number of cutting on the plots fertilized with 0 and $200 \mathrm{~kg} \mathrm{~N} / \mathrm{ha}$ (Figure 5). 


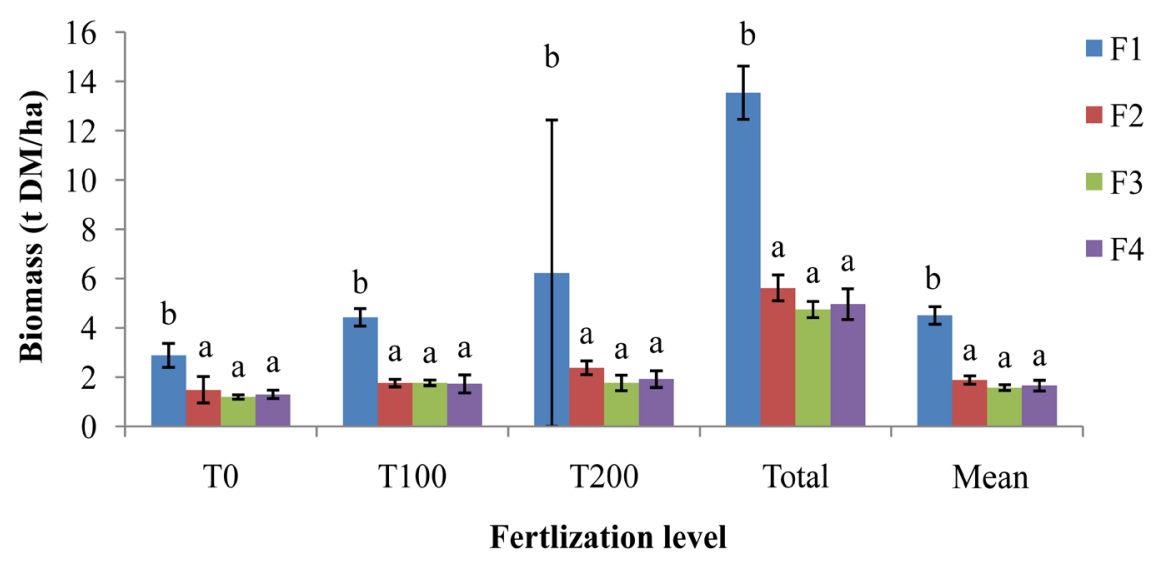

Figure 1. Variation of the biomass of $P$. clandestinum according to the number of cutting and of the fertilization to the hen droppings. a, b: The means carrying the same letters in the same column are not significantly different with the threshold from 5\%; F: Cutting.

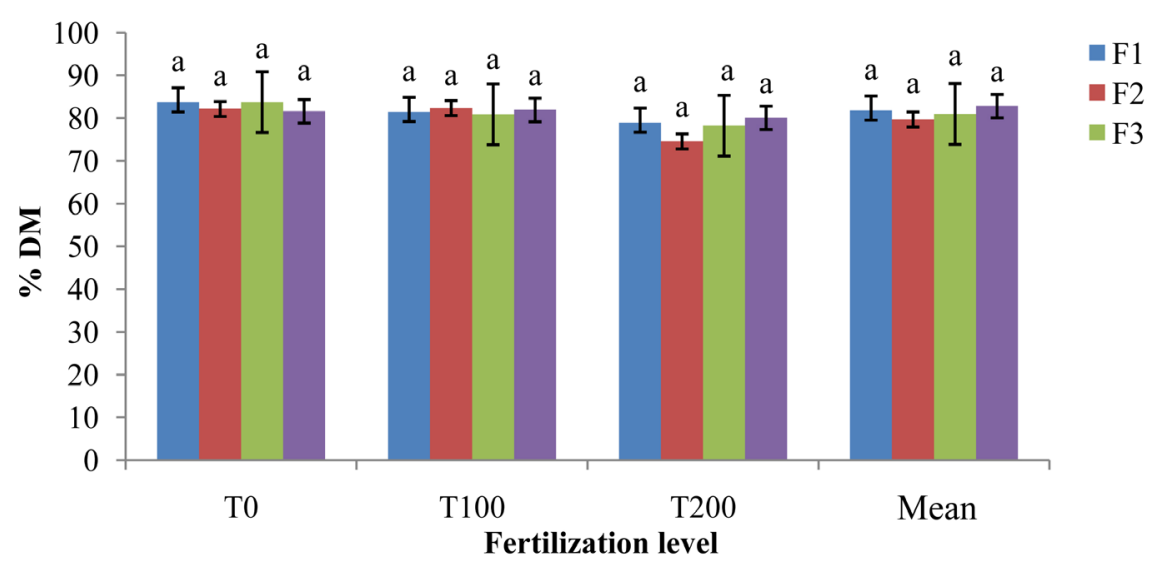

Figure 2. Variation of the dry matter content of $P$. clandestinum according to the number of cutting and the fertilization to hen droppings. F: Cuttings.

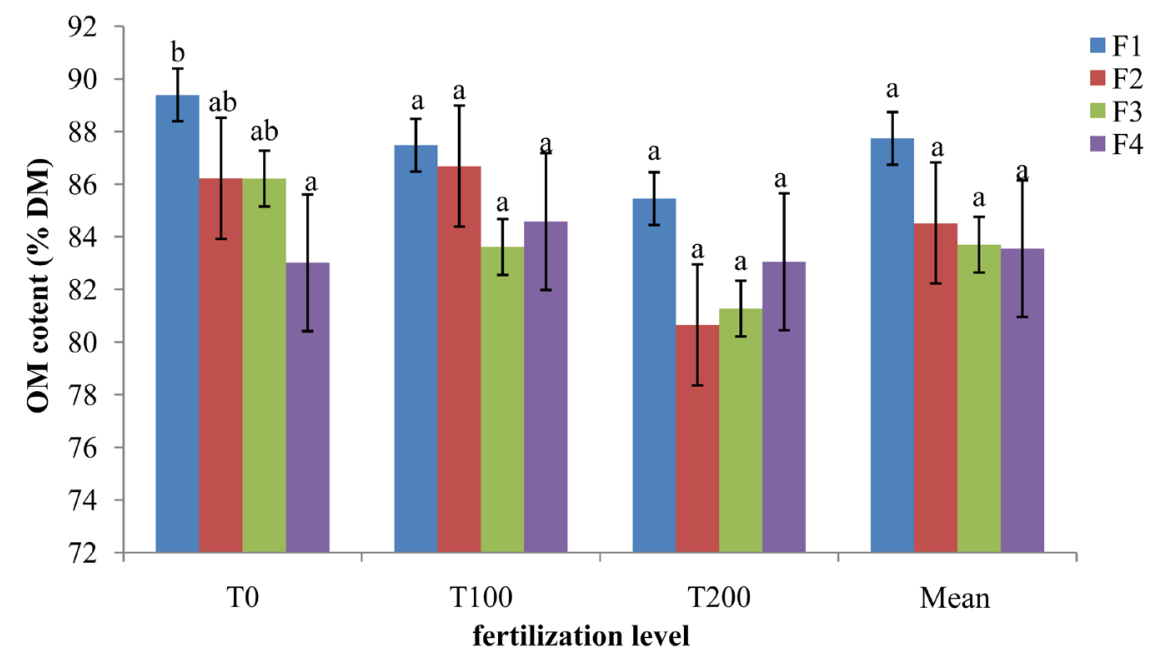

Figure 3. Variation of the content of organic matter (\%DM) of $P$. clandestinum according to the number of cutting and of the fertilization of the hen droppings. $a, b:$ The averages carrying the same letters in the same column are not significantly different with the threshold from 5\%; F: Cuttings. 


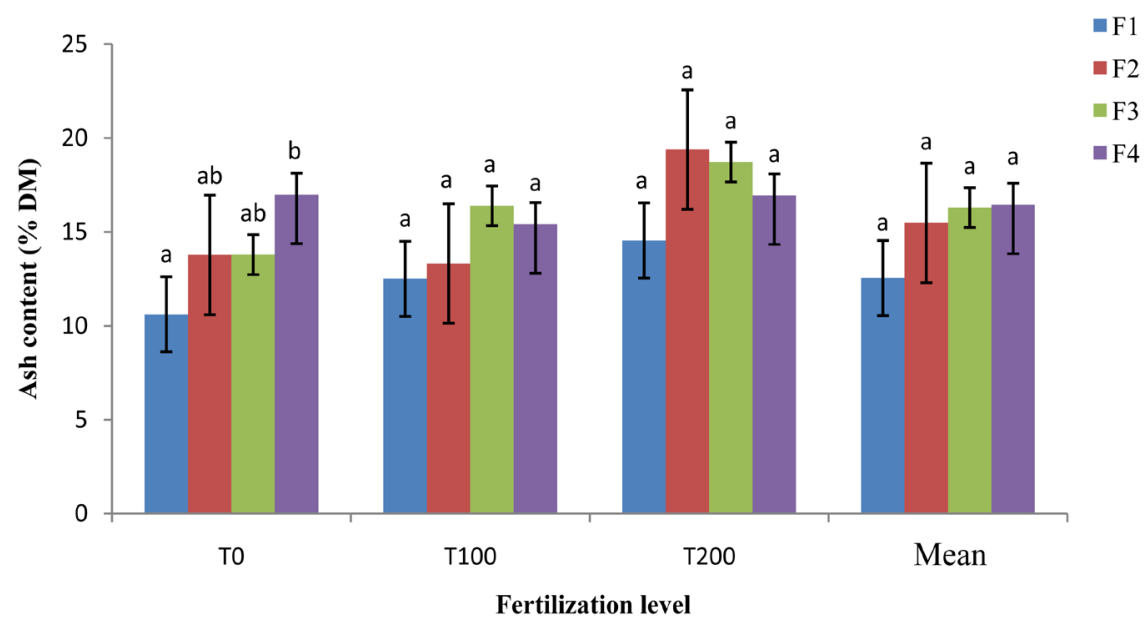

Figure 4. Variation of the ash content (\% DM) of $P$. clandestinum according to the number of cutting and of the fertilization to the hen droppings. a, b: The averages carrying the same letters in the same column are not significantly different with the threshold from 5\%; F: Cuttings.

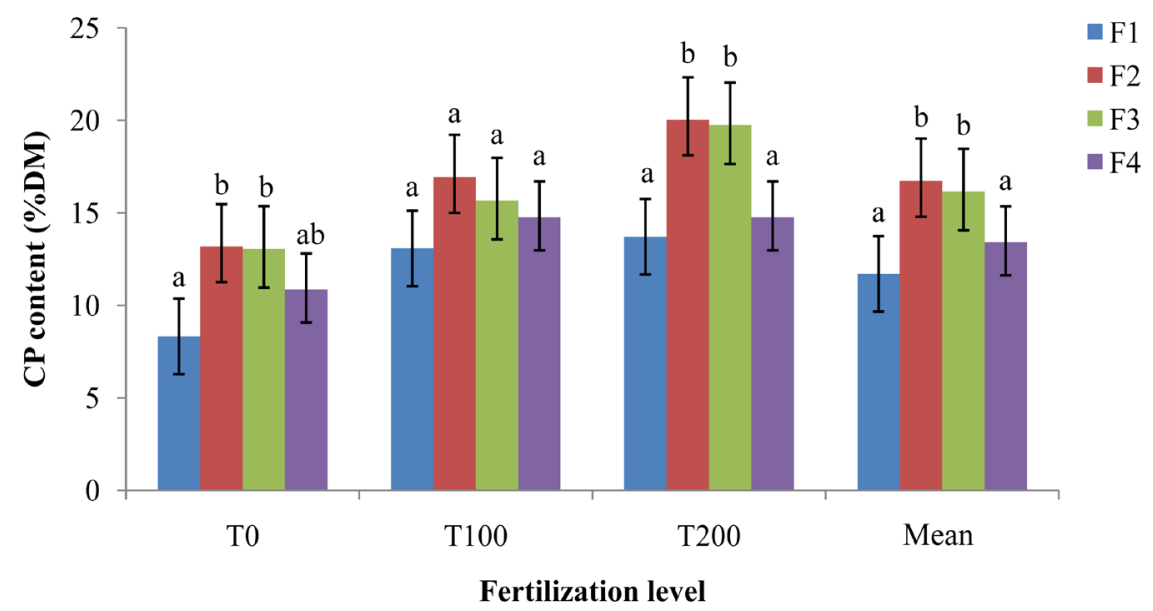

Figure 5. Variation of the CP content (\% DM) of $P$. clandestinum according to the number of cutting and of the fertilization to hen droppings. a, b: The averages carrying the same letters in the same column are not significantly different with the threshold from 5\%; F: Cuttings.

Indeed, the crude proteins contents increased with the number of cutting and this growth was significant $(\mathrm{p}<0.05)$ between the cuttings $\mathrm{F}_{1}$ and $\mathrm{F}_{2}$ and the cuttings $F_{1}$ and $F_{3}$. The rough protein contents of the three last cuttings remained comparable $(\mathrm{p}>0.05)$ between them for the amount $0 \mathrm{~kg} \mathrm{~N} / \mathrm{ha}$. In addition, the fodder rough protein content obtained on the fourth cutting remained comparable ( $p>0.05$ ) with that of the first fodder cut whatever the level of fertilization. With the amount $200 \mathrm{~kg} \mathrm{~N} / \mathrm{ha}$, the fodders of the second and third cutting firstly and between the first and fourth cutting secondly gave comparable crude protein contents $(p>0.05)$. No significant difference $(p>0.05)$ was observed between the various cuttings with the amount $100 \mathrm{~kg} \mathrm{~N} / \mathrm{ha}$. With the mean, the tendency remained the same as on the plots fertilized with $200 \mathrm{~kg} \mathrm{~N} / \mathrm{ha}$. 


\section{Discussion}

The regeneration of $P$. clandestinum was significantly improved with the level of fertilization to hens' droppings during the first cutting. This is due to the high nitrogen content of hen droppings and the presence of other nutritive elements which would have accelerated the plant growth. The absence of significant difference between regenerations to the other frequencies of cuttings can be explained by the stoloniferous development instead of foliar development or by the closer frequencies of cutting. Indeed, according to Voisin [21], frequent cuttings decrease height and plant potential to produce news regrowth. Njwe [22] explains this, by suggesting that the grazing ground or the cut of grass removes part or all photosynthetic tissue and carbohydrates reserves. However, with frequent defoliation, one could observe severe exhaustion of these reserves and consequently the plant exhaustion [23].

In this study, nitrogenized fertilization significantly influenced the production of $P$. clandestinum biomass. This observation is in line with those of many authors who have shown that nitrogen fertilization improves the production of forage plants [4] [24] [25] [26] [27]. The total biomass of $P$. clandestinum, obtained with the amount $100 \mathrm{~kg} \mathrm{~N} / \mathrm{ha}$ of hen droppings (9.7 t DM/ha) is similar to that brought back by Husson [6] which showed that the biomass production of this tropical graminaceous varies from 8 to $10 \mathrm{t} \mathrm{DM/ha/an.} \mathrm{Moreover,} \mathrm{these}$ outputs are lower than those obtained with the amount of $200 \mathrm{~kg} \mathrm{~N} / \mathrm{ha}(12.3 \mathrm{t}$ $\mathrm{DM} / \mathrm{ha}$ ). This variation of biomass production will be assigned due to the fact that beyond its important role in the soil nitrogen supply, the fertilization with hen droppings also brings other elements which influence its physicochemical and biological properties and its capacity to store water reserves [28]. Consequently, there will be an improvement in the nutritional conditions of the plant. The fall of the biomass with the interval of cutting observed in this study is in contradiction with the results of Stür et al. [29] Noumbissi [25] and Tendonkeng [4]. According to those authors, the best total output in biomass is obtained during over long periods of harvest. This result can be explained by the fact that cuttings intervals were brought closer not allowing the plant to carry out an effective renewal of photosynthetic fabrics and carbohydrates reserves. Indeed, Colman [30] had noted a reduction of $54 \%$ to $25 \%$ of dry matter yield of the cut of $P$. clandestinum with 14 days a regular interval of cutting, compared with the maximum production obtained with an interval of 84 days cutting.

Within this framework, the supplementation in nitrogenized elements in the practice of fertilization at various level of hen droppings had no significant effect on the content of dry matter of $P$. clandestinum only on the first and the second cutting. In addition, during all the duration of test, the content of dry matter dropped with the level of fertilization to hen droppings what is in agreement with the observations made by several authors such as Roberge and Toutain [31], Delaby [32]. They showed that the use of increasing quantities of nitrogen fertilization on grass meadows lead to a reduction in the dry matter content. In- 
deed, organic fertilization may increases the plant capacity to absorb water thus decreasing its dry matter content. However, the frequency of cutting did not affect the dry matter content whatever the level of fertilization to hen droppings used throughout this study.

During the probation period, organic matter content decreased with the level of fertilization to hen droppings. This result is contrary to those of Paillat [33] which reported that the nitrogen contribution does not modify the nutritional value of fodder. This contradiction can be attributed to the high percentage of minerals in hen droppings, which are absorbed by the plant thus decreasing the organic matter content.

Fertilization to hen droppings significantly influenced the ash content, with the first and the third cutting. Indeed, for these two cuttings, the plants of the control plot obtained a significantly lower ash content than those fertilized with $200 \mathrm{~kg} \mathrm{~N} / \mathrm{ha}$. The results of this study are in agreement with those of Tendonkeng [4], which observed that the minerals content of grazed grass was influenced by nitrogen fertilization. Indeed, the absorption of minerals must be adjusted to development speed of new vegetable fabrics, that is to the dynamics absorption and metabolism of nitrogen and carbon. During the test, we noticed an increase in the mean content of ash according to the frequency of cutting except with the pilot treatment. These results do not agree with the observations made by Chapman and Lemaire [23], Pamo [34] and Miegoue et Pamo [25] according to which the ash content decreases with the maturity of the plant. This will be probably due to the various components of hen droppings. Indeed, hen droppings have a raised proportion in minerals $(\mathrm{N}, \mathrm{P}, \mathrm{K}, \mathrm{Ca} . .$.$) which promote$ their assimilation over a long period by the plant.

The crude proteins content of $P$. clandestinum significantly increased with the level of fertilization to hen droppings. Indeed, in absence of nitrogenized fertilization, the rough proteins content of grass depends initially and especially on the availability of Soil nitrogen [31]. The amount of $200 \mathrm{~kg} \mathrm{~N} / \mathrm{ha}$ is the level of fertilization to hen droppings which permits to obtain the highest significant contents of rough protein of $P$. clandestinum. This result will be related to the strong proportion of nutritive elements present in hen droppings which make available and facilitate the absorption of nitrogen by the plants. Indeed, the entry of nitrogen in the plant which is carried out primarily in the form of nitrate increase quickly with the fertilization and, the release of nitrogen in the soil is done gradually according to the source of nitrogen used [4] [25] [31].

In this work, the rough protein fodders contents were significantly influenced by the frequency of cutting at various levels of fertilization. The reduction in the $\mathrm{CP}$ content with the frequency of cutting observed in this test is in agreement with the observations made by Cook et al. [35] and Chesworth [36]. These authors show that in the Tropics, fodders are of good nutritional value only at the beginning of rain season; they lignify very quickly and lose their nutrients content as the dry season approaches. In general, the $\mathrm{CP}$ content of grass decreases with the projection of the rainy season [3] [17] [37]. 


\section{Conclusion}

At the end of this study on the effect of various levels of fertilization to hen droppings on the production of biomass and the chemical composition of $P$. clandestinum cut at 30 days. The fertilization of hen droppings did not significantly influenced the regeneration of this plant fodder only on the first cutting. On the other hand, no significant difference was observed between the treatments as regards the other cuttings. The highest values of regeneration were obtained on the fertilized plots to $200 \mathrm{~kg} \mathrm{~N} / \mathrm{ha}$ whatever the frequency of cutting. The fertilization to hens' droppings significantly influenced the production of biomass of $P$. clandestinum at 30 days of cutting. Indeed, whatever the frequency of cutting the amount of $200 \mathrm{~kg} \mathrm{~N} / \mathrm{ha}$ gave the highest significant biomass. The biomass dropped with cutting frequency and the highest significant outputs were obtained with the first cutting. The fertilization to hen droppings influenced in a variable way the chemical composition of $P$. clandestinum. Indeed, the dry matter and organic matter contents dropped with the level of fertilization whereas those of ashes and rough proteins increased with the level of fertilization to hen droppings.

\section{Conflicts of Interest}

The authors declare no conflicts of interest regarding the publication of this paper.

\section{References}

[1] Gautier, D., Ankogui-Mpoko, G.F., Renoudji, F., Njoya, A. and Seignobos, C. (2005) Agriculteurs et éleveurs des savanes d'Afrique Centrale: De la co-existence à L'intégration territoriale. L'Espace Géographique, 3, 223-236. https://doi.org/10.3917/eg.343.0223

[2] Dongmo, A.L., Havard, M., Mbiandoun, M. and Njoya, A. (2007) Responsabilités sociétale et étatique dans la gestion des terroirs et des relations agriculture-élevage au Nord Cameroun: Vers un cadre de concertation, Revue Scientifique IRAD, Yaoundé, Juillet 2007.

[3] Pamo, T.E., Tendonkeng, F., Kana, J.R., Boukila, B. and Nanda, A.S. (2006) Effect Calliandra calothyrsus and Leucaena leucocephala Supplementary Feeding Goat Production in Cameroon. Small Ruminant Research, 65, 31-37. https://doi.org/10.1016/j.smallrumres.2005.05.023

[4] Tendonkeng, F. (2011) Effet de la fertilisation azotée, du stade phénologique et de l'année de fauche sur la croissance, le rendement et la valeur nutritive de Brachiaria ruziziensis Germain et Evrard. Thèse de Doctorat/PhD, Faculté d'Agronomie et des Sciences Agricoles, Université de Dschang, Cameroun, 186 p.

[5] Pamo, T.E., Boukila, B., Fonteh, F.A., Tendonkeng, F., Kana, J.R. and Nanda, A.S. (2007) Nutritive Values of Some Basic Grasses and Leguminous Tree Foliage of the Central Region of Africa. Animal Feed Science and Technology, 135, 273-282. https://doi.org/10.1016/j.anifeedsci.2006.07.001

[6] Husson, O., Michellon, R., Moussa, N., Charpentier, H., Enjalric, F., Naudin, K., Rakotondramanana and Seguy, L. (2012) Fiches techniques plantes de couverture: Légumineuses pérenne. http://agroecologie.cirad.fr 
[7] Obulbiga, M.F. and Kaboré-Zoungrana, C.Y. (2007) Influence de la fumure azotée et du rythme d'exploitation sur la production de matière sèche et la valeur alimentaire d Andropogon gayanus Kunth au Burkina Faso. Tropicultura, 25, 161-167.

[8] Berkić, S., Milakovic, Z., Kristek, A. and Antunovié, M. (2004) Pea Yield and Its Quality Depending on Inoculation, Nitrogen and Molybdenum Fertilization. Plant, Soil and Environment, 39, 39-45. https://doi.org/10.17221/3640-PSE

[9] Nono, E.I. (2015) Effet de la fertilisation organique sur la production de biomasse et la teneur en protéine de Brachiaria ruziziensis à la montaison. Mémoire d'Ingénieur Agronome. Productions animales, Université de Dschang, Cameroun, 32 p.

[10] Olanite, J., Ewetola, I.A., Onifade, O.S., Oni, O.A., Dele, P.A. and Sangodele, O.T. (2014) Comparative Residual Effects of Some Animal Manure on the Nutritive Quality of Three Tropical Grasses. International Journal of Science, Environment and Technology, 3, 1132-1139.

[11] Kamgue, T.A. (2016) Effet résiduel de la fertilisation organique sur la production de biomasse et la composition chimique de Brachiaria ruziziensis à la montaison. Mémoire d'Ingénieur Agronome. Productions animales, Université de Dschang, Cameroun, $40 \mathrm{p}$.

[12] Azangue, J.G., Nguetsop, V.F., Tendonkeng, F., Fokom, W.D. and Tedonkeng, P.E. (2019) Effets des différents niveaux de fertilisation aux fientes de poules sur la croissance et la production de biomasse de Brachiaria ruziziensis (Poaceae) en fonction des stades phénologiques à l'Ouest-Cameroun. International Journal of Biological and Chemical Sciences, 13, 1762-1774. https://doi.org/10.4314/ijbcs.v13i3.44

[13] Azangue, J.G., Tendonkeng, F., Nguetsop, V.F., Fokom, W.D. and Tedonkeng, P.E. (2019) Direct and Residual Effects of Different Levels of Chicken Manure Fertilization on the Growth and Biomass Production of Brachiaria ruziziensis (Poaceae) at the Bolting in West Cameroon. Agricultural Sciences, 10, 1113-1123. https://doi.org/10.4236/as.2019.108084

[14] Suchel, J.B. (1989) Les privilèges climatiques du pays Bamiléké. Les Cahiers d Outre-Mer, 165, 29-52. https://doi.org/10.3406/caoum.1989.3289

[15] Sanmarco, V. (1945) Les Bamilékè du district de Dschang. Exemple de l'influence du climat sur la vie indigène au Cameroun. Annales de Géographie. Bulletin de la Société de Géographie, 295, 223-224. https://doi.org/10.3406/geo.1945.12815

[16] Olivry, J.C. (1976) Régimes hydrologiques en pays Bamiléké (Cameroun). Cahier ORSTOM, Série Hydrologie, 13, 37-71.

[17] Pamo, T.E., Boukila, B., Fonteh, F.A., Tendonkeng, F. and Kana, J.R. (2005) Composition chimique et effet de la supplémentation avec Calliandra calothyrsus et Leucaena leucocephala sur la production laitière et la croissance des chevreaux nains de Guinée. Livestock Research for Rural Development, 17, Article No. 30. http://www.lrrd.org/lrrd17/3/tedo17030.htm

[18] Pauwels, J.M., Van Ranst, E., Verloo, M. and Mvondo Ze, A. (1992) Méthode d'analyse de sols et de plantes, gestion de stock de verrerie et de produits chimiques. Manuel de Laboratoire de Pédologie. Publications Agricoles, 28 p.

[19] AOAC (Association of Official Analytical Chemist) (1990) Official Method of Analysis. 15th Edition, AOAC, Washington DC.

[20] Steel, R.G. and Torrie, J.H. (1980) Principles and Procedures of Statistics. McGraw Hill Book C, New York, 633 p.

[21] Voisin, A. (1967) Productividad de la Hierba. In: Dinamica de los pastos, Trad. Ira. Ed. En Francés por Carlos de Cuenaca, Edit. Tecnos, S.A., Madrid, Espana.499 p. 
[22] Njwe, M.R. (1996) Animal nutrition and pastures. Distance education (course $\mathrm{n}^{\circ} 01$ AZ) University of Dschang.

[23] Chapman, D.F. and Lemaire, G. (1993) Morphogenic and Structural Determinants of Plant Regrowth after Defoliation. Proceedings XVII International Grassland Congress, Palmerston North, 8-21 February 1993, 95-104.

[24] Peyraud, J.L. (2000) Fertilisation azotée des prairies et nutrition des vaches laitières. Conséquences sur les rejets d'azote. INRAE Productions Animales, 13, 61-72.

https://doi.org/10.20870/productions-animales.2000.13.1.3769

[25] Noumbissi, M.N.B. (2007) Effet de la fertilisation azotée et de la fréquence de fauche sur la production, la composition chimique et la digestibilité in Vitro de Pennisetum clandestinum seul, ou mélangé au Leucaena LEUCOCEPHALA a Dschang, dans l'ouest-Cameroun. Mémoire de Master of science. Productions animales, Université de Dschang, Cameroun, $82 \mathrm{p}$.

[26] Miegoue, E. and Pamo, E.T. (2012) Effet de la fertilisation sur la valeur fourragère de $B$. ruziziensis. contribution à l'amélioration de la production et la qualité fourragère de Brachiaria ruziziensis. 108. édition-UE.com.

[27] Mboko, A.V., Tendonkeng, F., Matumuni, F.N.E., Zougou, G.T., Miégoué, E., Boukila, B. and Pamo, T.E. (2013) Effet comparé de deux légumineuses fertlisées au molybdène sur la croissance et le rendement de Brachiaria ruziziensis à différentes périodes de fauche dans l'Ouest Cameroun. International Journal of Biological and Chemical Sciences, 7, 2513-2525. https://doi.org/10.4314/ijbcs.v7i6.26

[28] Rouanet, G. (1984) Le maïs: Technicien d'Agriculture Tropicale. Agence de Coopération Culturelle et Technique. Ed. Maisonneuve et Larose, Paris, 142 p.

[29] Stür, W.W., Shelton, H.M. and Gutteridge, R.C. (1994) Defoliation Management of Forage Tree Legumes. In: Gutteridge, R.C. and Shelton, H.M., Eds., Forage Tree Legumes in Tropical Agriculture, CAB International, Wallingford, 158-167.

[30] Colman, R.L. (1966) Growth Curve Studies on Kikuyu Grass. Annual Report, Agricultural Research Station, Wollongbar, New South Wales, 1965-1966.

[31] Roberge, G. and Toutain, B. (1999) Choix des Cultures fourragères tropicales. In: Roberge, G. and Toutain, B., Eds., Cultures fourragères tropicales, CIRAD, Montpellier, 321-357.

[32] Delaby, L. (2000) Effect of Mineral Nitrogen Fertilization on the Feeding Value of Herbage and the Performance of Grazing Dairy Cows. Fourrage, 164, 421-436.

[33] Paillat, J.M., Rippstein, G., Huguenin, J., Marnotte, P. and Déat, M. (1999) Etablissement et entretien des prairies. In: Roberge, G. and Toutain, B., Eds., Cultures fourragères tropicales, CIRAD, Montpellier, 215-247.

[34] Pamo, T.E. (1991) Réponse de Brachiaria ruziziensis Germain et Evard à la fertilisation azotée et à différents rythmes d'exploitation en Adamaoua, Cameroun. Revue délevage et de médecine vétérinaire des pays tropicaux, 44, 373-380.

http://remvt.cirad.fr/cd/EMVT91_3.PDF

https://doi.org/10.19182/remvt.9180

[35] Cook, B.G., Pengelly, B.C., Brown, S.D., Donnelly, J.L., Eagles, D.A., Franco, M.A., Hanson, J., Muleen, B.F., Partridge, I.J., Peters, M. and Schultze-Kraft, R. (2005) Tropical Forages: An Interactive Selection Tool. CSIRO, DPI\&F (Qld), CIAT and ILRI, Brisbane.

[36] Chesworth, J. (1996) L'alimentation des ruminants. Edition Maisonneuve et Larose, CTA, 263 p. 
[37] Makkar, H.P.S. (2002) Application of the in Vitro Method in the Evaluation of Feed Resources, and Enhancement of Nutritional Value of Tannin-Rich Tree/Browse Leaves and Agro-Industrial By-Products. Proceeding of the Final Review Meeting of an IAEA Technical Co-Operation Regional AFRA Project, Cairo, 25-29 November 2000, 23-40. http://www-naweb.iaea.org/nafa/aph/public/iaea-tecdoc-1294.pdf 